(C) 2020 International Journal of Nursing and Midwifery Science (IJNMS)

This is an Open Access article distributed under the terms of the Creative Commons Attribution 4.0 International License which permits unrestricted non-commercial use, distribution, and reproduction in any medium, provided the original work is properly cited.

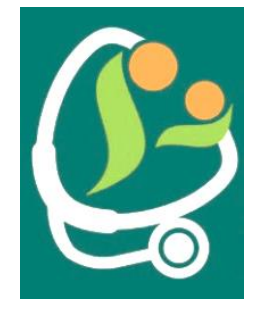

\title{
THE EFFECTIVENESS OF THE "BOMB" METHOD (BREASTCARE, OXYTOCIN MASSAGE, AND MARMET TECHNIQUE) ON INCREASING BREAST MILK PRODUCTION IN BREASTFEEDING MOMENTS AGE 0-6 MONTHS AT PRAMBON PUBLIC HEALTH CLINIC, NGANJUK DISTRICT
}

\section{Dwi Retno Wati, Siti Mudrikatin.}

STIKES Husada Jombang

Email : $\underline{\text { dwiretno485@gmail.com, Mudrisiti@Gmail.com }}$

\section{ABSTRACT}

The problem experienced by breastfeeding mothers is that the milk is not released on the first to the third day post partum. As a result, newborns who are supposed to be breastfed early will be delayed and as an alternative are given formula milk. The smoothness of the process of lactation or the production and production of breast milk is influenced by breast care, frequency of breastfeeding, maternal psychology, maternal health, and contraception, as well as breast milk production, which is strongly influenced by physical, psychospiritual, environmental and social. Efforts to stimulate the hormones prolactin and oxytocin can be done with breast care or massage, oxytocin massage, nipple cleansing, early and regular breastfeeding and marmet techniques or milking and massage techniques. The "BOM" method (Breastcare, Oxytocin Massage, and Marmet Technique) is a stimulation to help the production and release of breast milk through breast care, oxytocin massage (massage or stimulation of the spine) and marmet technique (a combination of expressing breast milk and massaging the breasts) ). Mothers breastfeeding babies aged 0-6 months at Public Health Clinic Prambon Nganjuk Regency in a preliminary study of 5 (five) mothers breastfeeding babies aged 0-6 months, do not know how to make a lot of milk production using "BOM" through structured interviews. The research objective was to assess the effectiveness of the BOM (Breastcare, Oxytocin, and Marmet Teachnique) method in increasing breast milk production. This study uses a quasi-experimental method. It was carried out at the Prambon Health Center with a total sample of 60 people and used the Mann Whitney U Test analysis. The results obtained from 60 samples were a $\mathrm{p}$ value of $0.000<0.05$, so it can be concluded that there were significant differences between the two groups, where the BOM method (Breastcare, Oxytocin, and Marmet Teachnique) was very effective on breast milk production.

\section{INTRODUCTION}

The smoothness of the process of lactation or the production and production of breastmilk is influenced by breast care, frequency of breastfeeding, maternal psychology, maternal health, and contraception. The decrease in breast milk production is also caused by a lack of the hormones prolactin and oxytocin which play a role in the lactation process. Efforts to stimulate the hormones prolactin and oxytocin can be done with breast care or massage, oxytocin massage, nipple cleansing, early and regular breastfeeding as 
well as marmet techniques or methods of expressing and massaging (Azriani \& Handayani, 2016).

Exclusive breastfeeding must be given within the first 6 months, so that the baby will achieve optimal growth and development. WHO / UNICEF recommends four things that must be considered in achieving optimal growth and development, namely breastfeeding immediately within 30 minutes after the baby is born, exclusive breastfeeding, giving complementary breastfeeding since the baby is 6-24 months old and continuing breastfeeding for up to 24 months (Tawiah-Agyemang, Kirkwood, Edmond, Bazzano, \& Hill, 2008). The incidence rate of starting breastfeeding in Indonesia in the results of research in Basic Health Research in Indonesia (Health Research and Development Agency, 2013), the percentage of starting breastfeeding is less than one hour ( $<1$ hour) $29.3 \%$, the process of starting breastfeeding 1-6 hours $40.7 \%$, the process of breastfeeding started $7-23$ hours $7.6 \%$, the process started breastfeeding $24-47$ hours $11.3 \%$, and the process started breastfeeding more than (> 48 hours) $11.1 \%$. The incidence rate of starting breastfeeding in provinces in East Java according to (Indonesian Ministry of Health, 2018), starting breastfeeding less than one hour $(<1$ hour $) 33.3 \%$, breastfeeding $1-6$ hours 37.5\%, breastfeeding 7-23 hours $6.3 \%$, breastfeeding $24-47$ hours $10.9 \%$, and breastfeeding more than 48 hours ( $>4$ hours) 12 was $12.1 \%$.

The "BOM" method (Breastcare, Oxytocin Massage, and Marmet Technique) is stimulation. to help produce and release breast milk through breastcare (breast massage), oxytocin massage (massage or stimulation of the spine) and marmet technique (a combination of expressing breast milk and massaging the breasts). The combination of breastcare, oxytocin massage, and marmet technique is a combination of three methods, namely breast massage through stimulation of the breast muscles, back to stimulate the breast glands to produce breast milk and trigger an increase in the hormone oxytocin for breastfeeding, in addition to the expressing technique which aims to empty breast milk so that it will stimulate the release of the hormone prolactin to produce breast milk (Neville, McFadden, \& Forsyth, 2002).

The results of research conducted by on (Darmasari, Putri, \& Rahmadaniah, 2019) the effectiveness of the combination of marmet technique and oxytocin massage on breast milk production indicate that the combination of the two can effectively increase breast milk production. Meanwhile, (Azriani \& Handayani, 2016) states that there is an effect of breast care on the smoothness of breast milk excretion. A feeling of comfort is also very important for a patient, so that during the implementation and after the implementation, it can be assessed how comfortable each client is if the BOM method is given or not. Research on the effect of the BOM method (Breastcare, Oxytocin Massage, and Marmet Teachnique) on breast milk production has not been carried out at this time. From the results of this research, it is hoped that the potential can be identified. The BOM method (Breastcare, Oxytocin Massage, and Marmet Teachnique) to increase milk production so that it can be applied as a way to stimulate

\section{METHOD}

This study uses a quasiexperimental method. The research design used two group pre test post test with control design. This research was conducted in the working area of the Prambon Health Center on February 6, 2020 to March 28, 2020. The population in this study were all 
breastfeeding mothers who had babies aged 0-6 months and were exclusively breastfeeding. The sample in this study were 60 mothers breastfeeding infants aged 0-6 months. The sample technique used is simple random sampling. Data analysis used was the Mann-Whitney U test (Nachar, 2008). The independent variable in this study is BOM (Breastcare, Oxytocin Massage, and Marmet Technique) with a nominal data scale. The dependent variable in this study is an increase in breast milk production on an ordinal scale. The instrument used in this study used an observation sheet to increase breast milk production which was carried out for 7 days. Validity is an index that shows the measuring instrument actually measures what is being measured(Maxwell, 1992). The technique used to determine parallels is the product moment correlation technique. The amount of $r$ count 0.869 . Reliability is an index that shows the extent to which a measuring device can be trusted or reliable (Maxwell, 1992). Reliability test was performed using the Cronbach's alpha formula. The reliability test was conducted on 20 respondents. The coefficient value obtained is 0.991 . The level of reliability can be done using SPSS through the Cronbach Alpha test compared to Table r. And the reliability in the table above can be seen that the Cronbach's Alpha value for all variables is greater than 0.60 so that the research instrument variables can be declared reliable.

Data processing using the SPSS16 computerized system. Data analysis used for the comparative test of two unpaired groups on data that was not normally distributed was using the Mann-Whitney U test (Gooch, 2011). Data analysis is done, namely managing data in a form that is easier to read and interpret and can be tested statistically. Data analysis was carried out in stages, namely univariate analysis aimed at obtaining an overview of each variable, both the dependent variable and the independent variable. Meanwhile, bivariate analysis was conducted to test the hypothesis between the independent variable and the dependent variable to see the effect between the independent variable and the dependent variable.

\section{RESULTS}

Table 1. Sample Characteristics Table (Data)

\begin{tabular}{llllll}
\hline $\begin{array}{llll}\text { Variabl } \\
\mathbf{e}\end{array}$ & $\mathbf{N}$ & $\begin{array}{l}\text { Mea } \\
\mathbf{n}\end{array}$ & SD & $\begin{array}{l}\text { Mi } \\
\mathbf{n}\end{array}$ & $\begin{array}{l}\text { Ma } \\
\mathbf{x}\end{array}$ \\
\hline Age & 6 & & 0,3 & & 3 \\
Breast & 0 & 1,97 & 2 & 1 & 11 \\
milk & 6 & 8,23 & 1,5 & 3 & \\
& 0 & & 9 & &
\end{tabular}

Based on the research data in Table 1, it shows that the average age and milk production of 30 subjects were (1.97), and (8.23), respectively. The age frequency distribution in this study can be presented in table 2.The following:

Table 2. Age Frequency Distribution

\begin{tabular}{llll}
\hline No & Age & Frequency & Percentage \\
\hline & $<20$ & & \\
& thn & & \\
1 & $20-$ & 16 & $36,70 \%$ \\
2 & 35 & 32 & $90,00 \%$ \\
3 & thn & 12 & $30 \%$ \\
Total & $>35$ & 60 & $100 \%$ \\
& thn & & \\
& & &
\end{tabular}

In table 2. above, of the 30 respondents who have $<20$ years of age there are 16 people $(6.70 \%), 32$ people aged 20-35 years $(90.00 \%)$, and 12 people aged $>35$ years ( $3.30 \%)$. This means that most of the postpartum mothers aged 20-35 years were 32 people $(90.00 \%)$. The distribution of the frequency of milk production in this study can be presented in table 3.The following: 
Table 3. Distribution of Breast Milk Production Frequency

\begin{tabular}{llll}
\hline No & $\begin{array}{l}\text { Breast } \\
\text { Milk } \\
\text { Producti } \\
\text { on }\end{array}$ & $\begin{array}{l}\text { Frequen } \\
\text { cy }\end{array}$ & $\begin{array}{l}\text { Percenta } \\
\text { ge }\end{array}$ \\
\hline 1 & medium & 32 & $53,30 \%$ \\
2 & low & 28 & $46.70 \%$ \\
Tot & & 60 & $100 \%$ \\
al & & & \\
\hline
\end{tabular}

In table 3. out of 30 respondents who have sufficient milk production, there are 16 people $(53.30 \%)$, less there are 14 people (46.70). This means that most of the respondents have breast milk production. Enough there are 16 people (53.30\%) of the total respondents studied.

Table 4. Statistical Test Results

\begin{tabular}{|c|c|}
\hline Test Statistics b & \\
\hline $\begin{array}{l}\text { Mann-Whitney U } \\
\text { Wilcoxon W } \\
\text { Z } \\
\text { Asymp.Sig. } \\
\text { tailed) } \\
\text { Exact Sig. [2*(1- } \\
\text { tailed Sig. })]\end{array}$ & $\begin{array}{l}\text { breast milk } \\
\text { production } 11.500 \\
131.500 \\
-4.309 \\
.000 \\
000\end{array}$ \\
\hline $\begin{array}{l}\text { a. } \quad \text { Grouping } \\
\text { Variable: } \mathrm{BOM}\end{array}$ & \\
\hline
\end{tabular}

Based on the table above, it shows that the $\mathrm{U}$ value is 11,500 and the $\mathrm{W}$ value is 131,500 . If converted to a $\mathrm{Z}$ value, the magnitude is 4,309 . The Sig or $P$ Value is $0.000<0.05$. If the $\mathrm{p}$ value <critical limit 0.05 , there is a significant difference between the two groups, which means H1 is accepted. So it can be concluded that the administration of the BOM method is very effective for increasing breast milk production in postpartum mothers.

\section{DISCUSSION}

In accordance with Tauriska (2014) research, in the nipples there are many sensory nerve endings. When stimulated, an implus appears to the hypothalamus then to the anterior pituitary gland (front part) so that this gland produces the hormone prolactin. The nipple stimulation is not only transmitted to the anterior pituitary gland, but also to the posterior pituitary gland (the back), which produces the hormone oxytocin.

Breastmilk production refers to the volume of milk released by the breasts. The intervention of the BOM method is principally aimed at making the myoepithel muscles contract, relaxing the mind and expediting breastfeeding. This expulsion of breast milk occurs because the smooth muscle cells around the breast glands constrict so that the milk squeezes out. Breast milk can come out of the breast due to the constricted muscles which can be stimulated by a hormone called oxytocin.

Through stimulation of breast massage or stimulation of the spine, it will relax tension and relieve stress, assisted by suction of the baby on the nipple as soon as the baby is born with a normal baby, neurotransmitters will stimulate the medulla oblongata to send messages to the hypothalamus in the posterior hypofia to release oxytocin, causing breasts release their milk (Tamari, 1970).

\section{CONCLUSIONS}

The $\mathrm{p}$ value is 0.000 < critical limit 0.05 , so it can be concluded that there is a significant difference between the two groups, where the BOM method (Breastcare, Oxytocin, and Marmet Teachnique) is very effective in increasing breast milk production. 


\section{REFERENCES}

Azriani, D., \& Handayani, S. (2016). The Effect of Oxytocin Massage on Breast Milk Production. Dama International Journal of Researchers (DIJR).

Darmasari, S., Putri, E., \& Rahmadaniah, I. (2019). Effectiveness of the combination of marmet technique and oxytocin massage against the breast milk production of mother postpartum. Jurnal Kedokteran Kesehatan: Publikasi Ilmiah Fakultas Kedokteran Universitas Sriwijaya. https://doi.org/10.32539/jkk.v6i3.9435

Gooch, J. W. (2011). Mann-Whitney U Test. In Encyclopedic Dictionary of Polymers. https://doi.org/10.1007/9781-4419-6247-8_15277

Health Research and Development Agency, H. M. (2013). Basic Health Research (RISKESDAS) 2013. In National Report 2013.

Indonesian Ministry of Health. (2018). Indonesia Basic Health Research 2018. Indonesian Ministry of Health.

Maxwell, J. (1992). Understanding and Validity in Qualitative Research. Harvard Educational Review. https://doi.org/10.17763/haer.62.3.832 3320856251826

Nachar, N. (2008). The Mann-Whitney U: A Test for Assessing Whether Two Independent Samples Come from the Same Distribution. Tutorials in Quantitative Methods for Psychology. https://doi.org/10.20982/tqmp.04.1.p0 13

Neville, M. C., McFadden, T. B., \& Forsyth, I. (2002). Hormonal regulation of mammary differentiation and milk secretion. Journal of Mammary Gland
Biology and Neoplasia. https://doi.org/10.1023/A:1015770423 167

Tamari, I. (1970). Audiogenic Stimulation and Reproductive Function. In Physiological Effects of Noise. https://doi.org/10.1007/978-1-46848807-4_11

Tawiah-Agyemang, C., Kirkwood, B. R., Edmond, K., Bazzano, A., \& Hill, Z. (2008). Early initiation of breastfeeding in Ghana: Barriers and facilitators. Journal of Perinatology. https://doi.org/10.1038/jp.2008.173 